\title{
PREVENTIVE MAINTENANCE AND ESSENTIAL OPTIMIZATIONS: A REVIEW
}

\author{
Shyam Patidar \\ Assistant Professor, Department of Mechanical Engineering \\ S.V.I.T.S. Shri Vaishnav Vidyapeeth Vishwavidyalaya, \\ Indore, M.P. India
}

\begin{abstract}
Proper maintenance is very essential for manufacturing machinery or assets. There are number of maintenance strategies but still preventive maintenance (PM) has big portion among all other strategies of maintenance to cure the plant asset. Achieve production goal by minimizing maintenance cost is very challenging due to uncertain maintenance parameter but need of present. Therefore role of optimization is very important to maximize availability of plant machinery for production and decrease the overall maintenance cost. Optimization of PM can eliminate unnecessary maintenance activities, decrease the cost of maintenance, reduce downtime, improve system reliability, provide safety etc. This research focuses on the role of $\mathrm{PM} \&$ maintenance management to cure plant assets and reviews the optimizations essential for PM.
\end{abstract}

Keywords - Optimization, Preventive Maintenance, Maintenance, Maintenance Management

\section{INTRODUCTION}

Today, the role of manufacturing industry is very important to fulfil the growing demand on time and for that the machinery running for the production must be in good condition and downtime must be minimum. To maintain the manufacturing machinery in good run condition and increase availability; they need a well planned maintenance strategy. Maintenance is not only limited to the machinery but it is grouping of administrative tasks, maintenance operations or technique adopted to restore the machines at optimal conditions so that it can perform its indented function [1]. Selection of optimal maintenance strategy for any of machine is very difficult task. Because there are many factors associated with maintenance like; cost, spare parts, maintenance operations and skilled labor, restoration time etc. [2]. There are several types of maintenance strategies such as breakdown maintenance, preventive maintenance (PM), predictive maintenance (PdM), condition based maintenance (CBM), reliability centred maintenance (RCM), total productive maintenance (TPM) etc. but still preventive maintenance (PM) is core maintenance strategy [3].

\section{PREVENTIVE MAINTENANCE}

$\mathrm{PM}$ is generally scheduled or time-interval based maintenance strategy to cure machinery. But rather than time-interval maintenance PM favours condition based maintenance as well as focus on reliability of the system or machinery. The aim of $\mathrm{PM}$ is to prevent failure or breakdown of machinery as well as prolong the life of machinery [4]. Further PM helps in:

- Prevent wear and tear or sudden failure

- Minimize production losses by reducing downtime

- Decrease cost of replacement

- Improves system reliability

- Enhance safety

These can be achieved through optimizing PM at every step. Effectiveness and efficiency of PM can be enhanced by optimization [3]. There are certain areas where the scope for optimization of PM such as minimize replacement cost and time, spare parts inventory, repair or replacement of the part(s) as per condition or age, optimize frequency of inspection etc. [5-7].

\section{MAINTENANCE MANAGEMENT}

Initially, maintenance was done when breakdown of any component occurred that's why it is known as breakdown maintenance. But the drawback is that after the maintenance again some problems revert back and sometimes the cost may be very high as well as operator safety is in danger [8]. Now a day the maintenance perspective has been totally changed and role of maintenance functions and responsibility not limited to the maintenance department or personnel; even management is equally responsible [9]. The management play a crucial role in making proper strategy and maintenance plan for optimal maintenance solution. However, it is very complex task to manage maintenance activities and operations [10]. Simoes et al. (2011) had reported that; the $25 \%$ of overall operational cost is incurred on maintenance [11]. Salonen and Deleryd (2011) mentioned in their research that; due to bad planning or unnecessary PM activities, cost $30 \%$ of total maintenance expenditure [12]. Proper planning and maintenance 


\section{International Journal of Engineering Applied Sciences and Technology, 2019 Vol. 4, Issue 3, ISSN No. 2455-2143, Pages 105-108 \\ Published Online July 2019 in IJEAST (http://www.ijeast.com)}



management can optimize replacement cost and time, inventory of spare parts, frequency of inspection etc.

\section{ESSENTIAL OPTIMIZATIONS FOR PM}

PM is very old maintenance strategy but still it has adopted in large portion for the maintenance of plant assets. At present, every production firm focused on fulfill the demand on time as well as ensure the availability of machinery. To increase the availability of machinery and prolong the life of plant asset; maintenance management ensure that the all the maintenance operations, required spare part inventory, maintenance cost, inspection frequency etc. must be optimize. Optimization of these achieved through only by balancing. The optimization of preventive maintenance can be done in following ways:

\section{A. Optimization of replacements in PM -}

There are two main areas 'replacement costs \& time' and 'inventory of spare parts'; where optimization is mainly concerned. Gilardonia et al. (2016) used Monte Carlo simulation method to determine PM's time and cost [13]. Mabrouk et al. (2016) used probability density function method to determine PM's time and cost [14] and Nourelfath et al. (2016) used Markov method [15]. Farran \& Zayed (2009) studied and determined the cost of repair by using Markov model [16]. Seif \& Rabbani (2014) determined replacement cost by using Integer Programming base mathematical model [17].

Overall maintenance cost significantly reduces, if the cost incurred on spare part inventory is optimum. Zahedi et al. (2017) studied spare part inventory optimization jointly with planned maintenance using simulation and flexible inventory management [18]. Siddique et al. (2018) developed a joint optimal maintenance and spare part inventory model assuming that the failure sequences follows Poisson process [19].

\section{B. Optimization of PM with repair-}

PM with repair is majorly on components age based and condition based; these two criteria optimize the cost of repair and the decision of repair mainly taken on the previous failure pattern depends on age or condition of the component. Many researchers [20-23] used probability density function based mathematical model and determine optimal economic age of components to repair.

Golmakani \& Pouresmaeeli (2014) determined optimal threshold replacement using probability density function based mathematical model for the components subjected to CBM [24]. Tang et al. (2015) identified the critical threshold by mathematical model based on semi-Markov decision method
[25]. Azadeh, et al. (2015) proposed an artificial intelligence based (Markovian discrete-event simulation) model and evaluated the effectiveness of CBM compare against to corrective maintenance and PM [26]. Peng \& Houtum (2016) proposed a joint optimization model for CBM and economic manufacturing quantity and estimated average long run cost rate [27].

\section{Optimization of inspection interval and frequency -}

The optimal inspection interval can result in maximum use the available resources thus it reduce the maintenance cost too. Optimal frequency of inspection will decrease the rate of failure of components or machinery and it will increase the mean time to failure (MTTF). Salonen \& Deleryd (2011) estimated the cost of inspection by applying Analysis Based Coasting (ABC) approach [12]. Chang (2014) analyzed PM policy for the systems subject to random working, replacement and minimal repair; and suggested properties of optimal preventive maintenance policy as well as a model to analyze maintenance policies [28]. Guo et al. (2015) proposed two models first minimizing short term cost rate and second long term cost rate to find out optimal inspection intervals [29]. Aghezzaf et al. (2016) proposed a practical approximate optimization model for the integration of production and imperfect PM planning in failure-prone manufacturing systems [30].

\section{Resource requirements optimization -}

The resource requirement optimizations mainly focused on fulfill the requirements of maintenance side by without disturbing the production or minimizing the production loss. Berrichi et al. (2009) proposed double-objective optimization algorithms for combine production and maintenance scheduling. They minimized the system availability for maintenance side (at optimal level) and provided best assignment solution for parallel machine problems [31]. Further Berrichi et al. (2010) extended the previous work to enhance the quality of solutions; they developed an algorithm based on Multi-Objective Ant Colony Optimization (MOACO) approach [32].

Sometime the maintenance activities of assets not done by own due to limited resources or other reasons and the maintenance services hired from outside on contract basis. To hire contract maintenance service, it must be optimize or compare the cost of contract and in-house maintenance cost component to component. Shaomin (2012) developed an approach to measure the profits of good PM actions, defined bonus functions (to pay bonus for quality PM) and get optimize solutions when PM is outsourced [33]. Hamidi et al. (2016) studied two game-theoretic models for lease contract. First is non-cooperative game-theoretical model; divided in 


\section{International Journal of Engineering Applied Sciences and Technology, 2019 Vol. 4, Issue 3, ISSN No. 2455-2143, Pages 105-108 \\ Published Online July 2019 in IJEAST (http://www.ijeast.com)}

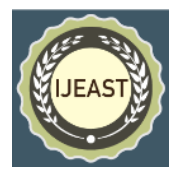

two lessee (contractor)-lessor (owner) model and leader (owner)-Follower (contractor) model and second is cooperative model. In lessee-lessor non-cooperative simultaneous move game they act simultaneously and take their decisions independently. In leader-follower noncooperative game owner make maintenance policies and contractor has to follow accordingly. In cooperative game, they target total profit maximization. Finally their results show that the lessee-lessor non-cooperative game model can gain more profit then others [34].

\section{CONCLUSION}

Maintain plant machinery in good conditions is difficult and challenging by without more disturbing the production. Achieve an optimal maintenance schedule with quality maintenance is very tough task. This review mainly focuses on the PM areas whereas the optimization is essential. The optimization of PM mainly focuses on the areas; optimization of replacements, optimization of PM with repair, optimization of inspection interval and frequency and resource requirements optimization. Also, reviewed those researches; which developed model or techniques to optimize maintenance policies and found optimal PM solutions.

\section{ACKNOWLEDGEMENT}

I am thankful to all authorities of Shri Vaishnav Vidyapeeth Vishwavidyalaya, Indore (M.P) for providing the needful for the completion of this work. I am also thankful to my colleagues for their constructive comments and suggestions.

\section{REFERENCE}

[1] Besnard F. (2013) "On maintenance optimization for offshore wind farms. Retrieved from" $\mathrm{PhD}$ thesis, http://www.elforsk.se/Global/Vindforsk/RapporterVFIII/ V_327_Besnard_Phd_thesis.pdf

[2] Patidar S., Patidar L. and Wararkar P. (2016) "Adoption of Maintenance Strategy for Plant Assets" IJSRD International Journal for Scientific Research \& Development, Vol. 4, Issue 04, pp. 361-363. ISSN (online): 2321-0613

[3] Shankar R., Pathak G., Suhane A. and Dwivedi R.K. (2015) "Optimization of Preventive maintenance: A review and analysis" International Journal of Engineering and Technical Research (IJETR), Volume-3, Issue-7, pp. 210-214.

[4] Mobley R. K., Higgins L. R. and Wikoff D. J. (2008) "Maintenance Engineering Handbook" 7th Edition, McGraw-Hill, NY.

[5] Jurca V., Hladik T. and Ales Z. (2008) "Optimization of preventive maintenance intervals" Eksploatacja i
Niezawodnosc - Maintenance and Reliability, vol. 3, pp. 41-44.

[6] Lee H. and Cha J. H. (2016) "New stochastic models for preventive maintenance and maintenance optimization" European Journal of Operational Research 255 (1), pp. 80-90. https://doi.org/10.1016/j.ejor.2016.04.020.

[7] Legat V., Mosna F., Cervenka V. and Jurca V. (2002) "Optimization of preventive maintenance and information system" In: Eksploatacja i Niezawodność- Maintenance and Reliability, 4, pp.24 -29.

[8] Parida A. \& Kumar U. (2007) "Maintenance Productivity and Performance Measurement" Handbook of Maintenance Management and Engineering, pp. 17-41.

[9] Ding S. H. \& Kamaruddin S. (2015) "Maintenance policy optimization: literature review and directions" International Journal of Advanced Manufacturing Technology, vol.76, issue 5-8, pp. 1263-1283. http://doi.org/10.1007/s00170-014-6341-2

[10]Patidar S. (2017) "Condition Monitoring and Maintenance Management for Precision Component Manufacturing Machines" International Research Journal of Engineering and Technology (IRJET), vol. 4, issue 12, pp. 383-385.

[11] Simoes C. F., Gomes C. F. and Yasin M. M. (2011) "A Literature Review of Maintenance Performance Measurement: A Conceptual Framework and Directions for Future Research" Journal of Quality in Maintenance Engineering, vol. 17, issue 2, pp. 116-137.

[12] Salonen A. and Deleryd M. (2011) "Cost of Poor Maintenance - A Concept for Maintenance Improvement" Journal of Quality and Maintenance Engineering, Vol. 17, Issue 1, pp. 63-73.

[13] Gilardoni G. L., Luiza M., Toledo G. De, Freitas M. A. \& Colosimo E. A. (2016) "Dynamics of an optimal maintenance policy for imperfect repair models" European Journal of Operational Research, vol. 248, issue 3, pp. 1104-1112. http://doi.org/10.1016/j.ejor.2015.07.056

[14] Mabrouk A. Ben, Chelbi A., \& Radhoui M. (2016) "Optimal imperfect maintenance strategy for leased equipment" Intern. Journal of Production Economics, vol. 178, pp. 57-64. http://doi.org/10.1016/j.ijpe.2016.04.024

[15] Nourelfath M., Nahas N. \& Ben-daya M. (2016) "Integrated preventive maintenance and production decisions for imperfect processes" Reliability engineering \& system safety, vol. 148, pp. 21-31.

http://doi.org/10.1016/j.ress.2015.11.015

[16] Farran M. \& Zayed T. (2009) "Comparative Analysis of Life-Cycle Costing for Rehabilitating Infrastructure Systems" Journal of Performance of Constructed Facilities, vol. 23, issue 5. 


\section{International Journal of Engineering Applied Sciences and Technology, 2019 Vol. 4, Issue 3, ISSN No. 2455-2143, Pages 105-108 \\ Published Online July 2019 in IJEAST (http://www.ijeast.com)}

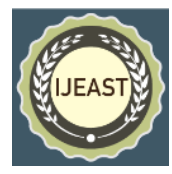

https://doi.org/10.1061/(ASCE)CF.1943-5509.0000038

[17] Seif J. \& Rabbani M. (2014)"Component based life cycle costing in replacement decisions" Journal of Quality in Maintenance Engineering, Vol. 20 Issue: 4, pp.436-452. https://doi.org/10.1108/JQME-08-2013-0053

[18]Zahedi-Hosseini F., Scarf P. and Syntetos A. (2017) "Joint optimisation of inspection maintenance and spare parts provisioning: a comparative study of inventory policies using simulation and survey data" Reliability engineering \& system safety, vol. 168, pp. 306-316. DOI:https://doi.org/10.1016/j.ress.2017.03.007

[19] Siddique P. J., Luong H.T. and Shafiq M. (2018) “An optimal joint maintenance and spare parts inventory model" Int. J. Ind. Syst. Eng. vol. 29, issue 2, pp. 17-192. https://doi.org/10.1504/IJISE.2018.091899

[20]Eti M. C., Ogaji S. O. T. \& Probert S. D. (2006) "Reducing the cost of preventive maintenance through adopting a proactive reliability-focused culture" Applied Energy, vol. 83, issue 11, pp. 1235-1248.

http://doi.org/10.1016/j.apenergy.2006.01.002

[21] Yeh R. H. \& Chang W. L. (2007) “Optimal threshold value of failure-rate for leased products with preventive maintenance actions" Mathematical and computer modelling, vol.46, issue 5-6, pp. 730-737.

http://doi.org/10.1016/j.mcm.2006.12.001

[22] Yeh R. H., Kao K. \& Chang W. L. (2009) “Optimal preventive maintenance policy for leased equipment using failure rate reduction" Computer and Industrial Engineering vol. 57, issue 1, pp. 304-309. http://doi.org/10.1016/j.cie.2008.11.025

[23] Chang W. \& Lo H. (2011) “Joint determination of lease period and preventive maintenance policy for leased equipment with residual value" Computers \& Industrial Engineering, vol. 61, issue 3, pp. 489-496.

http://doi.org/10.1016/j.cie.2011.04.003

[24] Golmakani H. R. \& Pouresmaeeli M. (2014) “Optimal replacement policy for condition-based maintenance with non-decreasing failure cost and costly inspection" Journal of Quality in Maintenance Engineering, vol. 20 issue 1, pp.51-64. https://doi.org/10.1108/JQME-12-2012-0044.

[25] Tang D., Yu J., Chen X. \& Makis V. (2015) “An optimal condition-based maintenance policy for a degrading system subject to the competing risks of soft and hard failure" Computers \& Industrial Engineering, vol. 83, pp. 100-110. http://doi.org/10.1016/j.cie.2015.02.003

[26] Azadeh A., Asadzadeh S. M., Salehi N. \& Firoozi M. (2015) "Condition-based maintenance effectiveness for series-parallel power generation system-A combined Markovian simulation model" Reliability Engineering and System Safety, vol. 142, pp.357-368.

http://doi.org/10.1016/j.ress.2015.04.009
[27] Peng H. \& Houtum G. J. Van (2016) "Joint optimization of condition-based maintenance and production" European Journal of Operational Research, vol.253, issue 1, pp.94-107. http://doi.org/10.1016/j.ejor.2016.02.027

[28]Chang C. (2014) "Optimum preventive maintenance policies for systems subject to random working times, replacement and minimal repair" Computers \& Industrial Engineering, vol. 67, pp.185-194.

http://doi.org/10.1016/j.cie.2013.11.011

[29] Guo H., Szidarovszky F., Gerokostopoulos A. and Niu, P. (2015) "On determining optimal inspection interval for minimizing maintenance cost" Annual Reliability and Maintainability Symposium (RAMS), Palm Harbor, FL, pp.1-7.

[30] Aghezzaf E., Khatab A. \& Le P. (2016) “Optimizing production and imperfect preventive maintenance planning's integration in failure-prone manufacturing systems" Reliability Engineering and System Safety, vol.145, pp.190-198.

http://doi.org/10.1016/j.ress.2015.09.017

[31] Berrichi A., Amoedo V, Yalaoui F., Chetelet E. \& Mezghiche M. (2009) "Bi-objective optimization algorithms for joint production and maintenance scheduling: application to the parallel machine problem" Journal of Intelligent Manufacturing, Springer, vol. 20, pp.389-400. https://doi.org/10.1007/s10845-008-0113-5

[32] Berrichi A., Yalaoui F., Amoedo L. \& Mezghiche M. (2010) "Bi-objective Ant Colony Optimization approach to optimize production and maintenance scheduling" Computer and Operations Research, vol. 37, issue 9, pp.1584-1596.

https://doi.org/10.1016/j.cor.2009.11.017

[33] Shaomin Wu (2012) “Assessing Maintenance Contracts when Preventive Maintenance is Outsourced" Reliability Engineering and System Safety, vol. 98, issue 1, pp. 6672. https://doi.org/10.1016/j.ress.2011.10.004

[34] Hamidi M., Liao H. and Szidarovszky F. (2016) "Noncooperative and cooperative game theoretic models for usage-based lease contracts" European Journal of Operational Research, vol. 255, issue-1, pp.163-174. https://doi.org/10.1016/j.ejor.2016.04.064 